Article

\title{
Distribution of Viable Bacteria in the Dust-Generating Natural Source Area of the Gobi Region, Mongolia
}

\author{
Katsuro Hagiwara ${ }^{1, *(\mathbb{D})}$, Tamaki Matsumoto ${ }^{2}$, Purevsuren Tsedendamba ${ }^{2}$, Kenji Baba $^{2} \mathbb{D}$ and \\ Buho Hoshino $2, *$ (D) \\ 1 School of Veterinary Medicine, Rakuno Gakuen University, Ebetsu, Hokkaido 069-8501, Japan \\ 2 Department of Environmental and Life Sciences, Rakuno Gakuen University, \\ Ebetsu, Hokkaido 069-8501, Japan; matumototamaki24@gmail.com (T.M.); \\ pujee_ts@yahoo.com (P.T.); kbaba@rakuno.ac.jp (K.B.) \\ * Correspondence: k-hagi@rakuno.ac.jp (K.H.); aosier@rakuno.ac.jp (B.H.); \\ Tel.: +81-11-388-4826 (K.H.); +81-11-388-4913 (B.H.)
}

Received: 1 August 2020; Accepted: 21 August 2020; Published: 24 August 2020

\begin{abstract}
The Gobi Desert is a major source of dust events, whose frequency of occurrence and damage caused have recently significantly increased. In the present study, we investigated the types of live bacteria present in the surface soil of the Gobi Desert in Mongolia, and determined their genetic identification as well as their geographical distribution. During the survey, four different topographies (dry lake bed, wadi, well, and desert steppe) were selected, and land characteristics were monitored for moisture and temperature. The surface soil was aerobically cultured to isolate bacterial colonies, and their $16 \mathrm{~s}$ rDNA regions were sequenced. The sequence data were identified through NCBI-BLAST analysis and generated phylogenetic trees. The results revealed two phyla and seven families of isolates from the sample points. Each isolate was characterized by their corresponding sample site. The characteristics of land use and soil surface bacteria were compared. Most of the bacteria originated from the soil, however, animal-derived bacteria were also confirmed in areas used by animals. Our findings confirmed the existence of live bacteria in the dust-generating area, suggesting that their presence could affect animal and human health. Therefore, it is necessary to further investigate dust microbes based on the One Health concept.
\end{abstract}

Keywords: bacteria; Asian dust storm; dust-generating sources region; Gobi Desert; field and laboratory experimental method

\section{Introduction}

Transboundary infectious diseases are currently increasingly problematic [1-3], as they originate from viruses and bacteria which can threaten human and animal health. They occur not only through the development of socio-economic activities but also via the atmospheric circulation from climate change [4]. Dust events especially have long been considered a negative factor in transboundary mass transfer [5-7]. No detailed search has been done for the distribution of viable bacteria on the surface of the dust-producing areas. In order to understand the problems associated with this outbreak risk, a basic analysis of the outbreak site is essential. The Asian dust event is an event where a large amount of dust is blown by strong winds due to the occurrence of low pressure in arid/semi-arid areas such as the desert region of East Asia and the Loess Plateau. This dust is then carried by a westerly wind and floats in northeast Asia as well as the western Pacific Ocean. This is followed by scattering, descent, and deposition [8]. The conditions for the generation of Asian dust are (1) a large amount of dry sand dust (0.1-0.3 $\mathrm{mm}$ in diameter) and dust (0.25-0.0036 $\mathrm{mm}$ in diameter) present in the area 
of occurrence; (2) the presence of an updraft due to low pressure at the site of occurrence; (3) the presence of a strong westerly wind above the site of occurrence [9-11]. In spring, dust storms occur in the Gobi Desert in China and Mongolia, as well as in the Hebei Corridor and the Loess Plateau region $[12,13]$. Dust storms are a meteorological phenomenon in which a large amount of mineral dust blown up by a strong wind from the desert area is carried by the wind in the sky and floats while descending. They not only significantly reduce visibility near the surface of the earth, but also cause significant damage to human activities such as agricultural production and transportation, as well as to human health by affecting respiratory organs $[14,15]$. The factors responsible for dust storms are meteorological conditions (strong winds, low pressures, and updrafts) that presuppose occurrence, and the ground surface conditions (soil moisture content, snowfall, and vegetation) that exist under those conditions [16-18].

The particle size of the yellow sand that arrives in Japan is 1-30 $\mu \mathrm{m}$ in diameter, including $\mathrm{PM}_{2.5}$ (particles with a diameter of $2.5 \mu \mathrm{m}$ or less). The size of most of the dust particles flying to Japan was reported to be about $4 \mu \mathrm{m}$ in diameter (Ministry of the Environment yellow sand chemical component analysis data, 2002) $[15,19,20]$. Yellow sand arriving in Japan is of low concentration but made up of fine particles, and its arrival time overlaps with the pollen release from cedar and cypress trees. As the incidence of respiratory conditions such as bronchial asthma in children is increased in connection with this phenomenon, concerns regarding the effects of allergies on human health become highlighted, raising public anxiety. In addition, infectious microorganisms may attach themselves to dust particles and be transported over long distances, consequently highlighting the role of the latter as a cross-border pollutant [21]. It has been reported that bacteria in the Gobi area attach to soil particles and disperse due to the dust phenomenon [22]. Previous findings have indicated that various yellow sand bioaerosols containing pathogenic microorganisms become scattered, and that spores resistant to ultraviolet rays and drought in particular have been found to survive in the air $[23,24]$.

Bioaerosol is airborne particulate matter derived from living organisms, including microorganisms such as bacteria, viruses, pollen, and organic dust [25]. Bacteria may roll up with sand dust due to the dust storm phenomenon, attach to the dust particles, and be transported over long distances. The presence of Bacillus sp. has also been confirmed over the Taklamakan Desert, which is a dust-producing area, as well as over Dunhuang City, China and Suzu City, Japan (100-800 m in altitude) [26]. Of health concern are particles less than $10 \mu \mathrm{m}$ in size that can penetrate the lungs. Furthermore, particles smaller than $2.5 \mu \mathrm{m}$ are capable of penetrating deep lung tissues, and these particles cause adverse health effects via oxidative stress [27]. Furthermore, the greatest risk factors for these components are frequency of exposure, particle concentration and composition, and immunological effects. In particular, it has been suggested that dust-borne microorganisms may have a direct impact on human health through etiology, exposure as an allergen, and increased susceptibility to asthma due to long-term exposure [28,29]. If environmental bacteria are zoonotic or risk factor for human health, they can directly affect livestock or humans or indirectly via animals. Although it exists in the environment, it has the potential to be versatile in its host range due to its susceptibility, and a One Health concept is required. The aim of the present study was to characterize bacteria found in the soil of the Gobi area (a source of dust), in consideration of the differences in land conditions of the tested topographies, and provide fundamental information on the effects of these bacteria on human health.

\section{Materials and Methods}

\subsection{Sample Collection}

The sampling area was set up around the Sainshand $\left(44^{\circ} 53^{\prime} \mathrm{N}, 110^{\circ} 08^{\prime} \mathrm{E}\right)$ in Dornogovi aimag, located in the southern part of Mongolia (Figure 1), with the Gobi Desert extending around it. The extremely dry Gobi Desert, along with the Loess Plateau and Taklamakan Desert, is one of the sources of Asian dust and drifting dust storms [30]. From April to May 2017 and 2018, the generated yellow sand was classified into the four locations described below, based on the land characteristics 
around the Sainshand, Dornogovi aimag, Mongolia, and sampling was performed by collecting soil from three points in each land type. The sources for figures are listed as follows: Digital Elevation data from the SRTM (The Shuttle Radar Topography Mission) [31]; and satellite imagery from Sentinel 2 of ESA (European Space Agency) [32], and image processing using Golden Software Sufer [33].

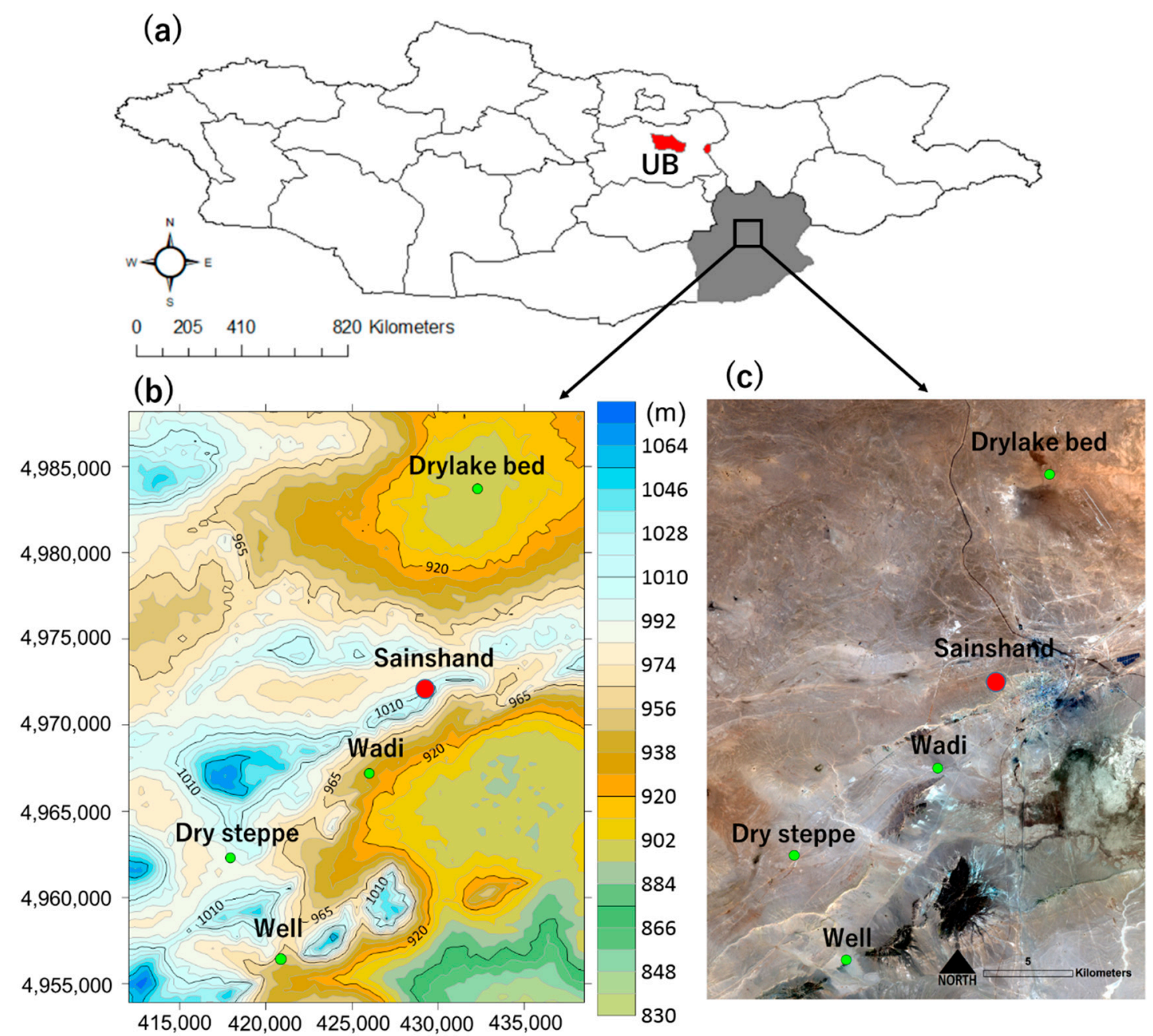

Figure 1. Geographical location of the study area. The sample site on the west side of the investigated dust source in Mongolia is shown on the map. The study site is a terrain with an elevation ranging from $1311 \mathrm{~m}$ to $692 \mathrm{~m}$, with four sample points: dry lake bed, desert steppe, wadi, and well. (a) Map of Mongolia. (b) The topographic contours of the study site DEM (Digital Elevation Model data sources are from SRTM (The Shuttle Radar Topography Mission); the spatial resolution is 1 arc-second for global coverage, download from (CUSGS Earth Explorer; and topographic contour (TC) files were made using Surfer, Golden Software $\left.{ }^{\circledR}\right)$. The values on the vertical and horizontal axes indicate distances (m) on UTM (Universal Transverse Mercator) North 48 zone and the World Geodetic System (WGS) 84 projection. (c) The sampling points on Sentinel 2 satellite imagery (The Copernicus Sentinel-2 mission data download from The Copernicus Open Access Hub. R-G-B color composition used band4 (red), band3 (green), and band2 (blue) of Sentinel 2 imagery; the spatial resolution is $10 \mathrm{~m}$ ).

\subsection{Classification of Land Use}

The study area was set up in four different locations, classified according to their land use: dry lake bed, wadi, well, and desert steppe.

(1) Dry lake bed (DL): A dry lake bed is a source of dust storm, and is a site where water flowed without the presence of plants. It is a place where various substances accumulate due to the development of water catchment networks and the elevation above the surrounding area, and where 
soil particles also accumulate. Geographically and topographically, a dry lake is referred to as the inland depression (playa), which is a shallow plain during the rainy season, but which, following evaporation, turns into a salt plain, where sediments such as clay, salt, and gypsum remain [12]. Dry lake beds occupy approximately $1 \%$ of the total area of the Gobi Desert; the surface temperature was $38.4 \pm 1.18^{\circ} \mathrm{C}$, and soil moisture was $7.2 \pm 0.37 \%$ (Table 1). Dry lake beds in lower elevations are understood to be part of a well-developed river network, where small particles on the bare surface are deposited in the dry lake by rainfall and wind. Rashki et al. (2013) determined that the dryness of lakes in the Hamoun basin was strongly associated with changes in land-atmosphere fluxes, soil moisture, frequency, and intensity of dust storms [34]. In the present study, the frequency of dry lake bed formation was compared with the interannual variability of precipitation in order to identify the time of dry lake bed appearance in the study area.

Table 1. Ground surface temperature and volumetric water content in Gobi Desert.

\begin{tabular}{ccc}
\hline Place & Ground Surface Temperature $\left({ }^{\circ} \mathbf{C}\right)$ & Volumetric Soil Water Content (\%) \\
\hline Dry lake bed & $38.4 \pm 1.18$ & $7.2 \pm 0.37$ \\
Wadi & $37.7 \pm 1.18$ & $3.2 \pm 0.13^{*}$ \\
Well & $35.7 \pm 1.50$ & $3.7 \pm 0.25^{*}$ \\
Desert Steppe & $30.2 \pm 0.33^{*}$ & $5.0 \pm 0.40 *$ \\
\hline
\end{tabular}

* There is a significant difference between dry lake bed and desert Steppe $(p<0.001)$. * Wadi, well, and desert steppe were significantly different from the dry lake bed $(p<0.0001)$.

(2) Wadi (WA): A wadi is a dry channel formed on low terrain, where small particles on the bare surface are also deposited. It is a seasonal river that temporarily appears during precipitation in the rainy season. In the dry season, the river water is depleted and becomes a dry river. Wadis occupy approximately $1 \%$ of the total Gobi area; the surface temperature was $37.7 \pm 1.18^{\circ} \mathrm{C}$, and soil moisture was $3.2 \pm 0.13 \%$ (Table 1 ).

(3) Well (WE): In the Gobi Desert, only one well is distributed within a radius of 20-30 km. The area around the well is a hot spot for pasture degradation by livestock and wildlife. The surface temperature was $35.7 \pm 1.50{ }^{\circ} \mathrm{C}$, and soil moisture was $3.7 \pm 0.25 \%$ (Table 1 ).

(4) Desert steppe (DS): The desert steppe was the most widely distributed land type, occupied by grazing sheep, goats, cows, and camels. The presence of annual perennials and shrub perennials, involved in the control of dust storms, was observed in this area. Additionally, livestock and animal dung were identified in the vicinity. The desert steppe occupies approximately $70 \%$ of the total Gobi area; the ground surface temperature was $30.2 \pm 0.33^{\circ} \mathrm{C}$, and soil moisture was $5.0 \pm 0.40 \%$ (Table 1 ). The vegetation of the Gobi Desert mainly consists of perennial shrub plants and annual herb plants. A perennial plant survives for several years, while an annual plant germinates from seeds, grows within one year to flower and fruit, and produces seeds before dying. In addition to these land uses, the Gobi Desert occupies approximately $27-28 \%$ of the mountain (rock) zone. This research project is based on the following project: "International Observation of Asian Dust and Environmental Regime shift over the Source Regions", Grants-in-aid Scientific Research (A: 16H02703). The analysis of the survey sample was conducted with the permission of the plant quarantine station for agriculture, forestry and fisheries (29Y2490).

\subsection{Experimental Method}

\subsubsection{Bacterial Isolation and Culture}

For bacterial culture, surface soil was collected in a sterile container and suspended in $10 \%$ sterile phosphate buffered saline (PBS) solution. The suspension was diluted to $10^{-1}-10^{-5}$ in PBS solution and aerobically cultured in LB medium (Difco ${ }^{\mathrm{TM}} \mathrm{LB}$ agar, Miller, BD, NJ, USA) at $37^{\circ} \mathrm{C}$ for $24 \mathrm{~h}$. The generated colonies were first counted as total number of bacteria and classified by morphology based on Bergey's Manual [35]. DNA was subsequently extracted from three colonies of the same 
morphology from each sample location using the MagExtractor ${ }^{\mathrm{TM}}-$ Genome-kit (Toyobo, Osaka, Japan) according to the manufacturer's instructions.

\subsubsection{Amplification of $16 \mathrm{~s} \mathrm{rDNA}$ and Determination of Gene Sequence}

Amplification of 16s rDNA was performed using the extracted DNA as a template, as well as primers 27F (5'-AGAGTTTGATCMTGGCTCAG-3') and 1492R (5'-CGGTTACCTTGTTACGACTT-3'). Gene amplification was carried out by polymerase chain reaction (PCR), using TaKaRa Ex Taq ${ }^{\circledR}$ (Takara Bio Inc., Shiga, Japan) as follows: an initial denaturation at $95^{\circ} \mathrm{C}$ for $2 \mathrm{~min}$, followed by thermocycling (35 cycles) at $98{ }^{\circ} \mathrm{C}$ for $10 \mathrm{~s}, 55^{\circ} \mathrm{C}$ for $30 \mathrm{~s}$, and $72{ }^{\circ} \mathrm{C}$ for $1 \mathrm{~min}$, and a final extension at $68{ }^{\circ} \mathrm{C}$ for $5 \mathrm{~min}$. DNA amplicons were resolved on $1.0 \%$ agarose gel via electrophoresis, and an amplified band $1466 \mathrm{bp}$ in length was confirmed. Amplified DNA was purified using the Fast Gene ${ }^{\mathrm{TM}} \mathrm{Gel} / \mathrm{PCR}$ Extraction Kit (Genetics, Tokyo, Japan) for the preparation of samples for direct sequencing. Sequence analysis was performed using the 27F sequence primer. The resulting nucleotide sequence was aligned using Bio Edit (Version 7.0.9) [36]. The 16s rDNA variable regions 1-4 were subjected to BLAST analysis using the GenBank database (NCBI) in order to identify bacteria based on their previously determined classification.

\subsection{Sample Data Analysis}

The water content and temperature of soil collected at the sample points were measured using dedicated measuring instruments, i.e., the HH2 Moisture Meter $@$ (Delta-T Devices Ltd., Cambridge, UK), and a radiation thermometer (Shinwa Rules Co., Ltd., Niigata, Japan), respectively. Their relationship with the total number of bacteria in each land was statistically analyzed. ANOVA and the Tukey-Kramer tests were performed using Microsoft ${ }^{\circledR}$ Excel (Ver. 2016). In addition, the correlation between soil moisture content and total bacterial count for each land use was calculated as the correlation coefficient. Phylogenetic analysis of the detected bacteria was determined, and phylogenetic tree analysis was performed by the neighbor-joining method using MEGA-X (Verson 10) [37].

\section{Results}

\subsection{Soil Moisture Content and Surface Temperature of Each Land Use}

The soil water content of each land type is shown in Table 1. From the results of the Tukey-Kramer and Bonferroni tests obtained for the water content, a significant difference $(p<0.0001)$ was found in the water content between DL and WA, DL and WE, and DL and DS (Table 1). From the results of the Tukey-Kramer and Bonferroni tests for surface temperature, a significant difference $(p<0.001)$ was observed in the surface temperature between DL and DS (Table 1).

\subsection{Total Number of Bacteria in Each Sample Point}

The total number of bacteria in each region was as follows: $7 \times 10^{6} \mathrm{CFU}$ (colony forming unit) $\mathrm{g}^{-1}$ for DL, $2 \times 10^{6} \mathrm{CFU} \mathrm{g}^{-1}$ for WA, $10^{7} \mathrm{CFU} \mathrm{g}^{-1}$ for WE, and $8 \times 10^{6} \mathrm{CFU} \mathrm{g}^{-1}$ for DS (Table 2). The highest number of isolated bacteria was detected in WE, while the lowest was in WA. However, no significant difference was found in the total number of bacteria within the same sample area. In addition, no correlation was found between soil water content and total bacterial count in each sample point. 
Table 2. Detection of Microbes in Gobi Desert.

\begin{tabular}{|c|c|c|c|c|}
\hline Place & Phylum & Family & Species & $\begin{array}{c}\mathrm{CFU}{ }^{*} \\
\left(\mathrm{CFU} \mathrm{g}^{-1}\right)\end{array}$ \\
\hline \multirow{3}{*}{ Dry lake bed } & Firmicutes & Bacillaceae & Bacillus sp. & $6 \times 10^{6}$ \\
\hline & Actinobacteria & Micrococcaceae & Arthrobacter sp. & $2 \times 10^{5}$ \\
\hline & Firmicutes & Staphylococcaceae & Staphylococcus sp. & $1 \times 10^{5}$ \\
\hline \multirow{3}{*}{ Wadi } & Firmicutes & Planococcaceae & Planomicrobium sp. & $2 \times 10^{6}$ \\
\hline & Actinobacteria & Micrococcaceae & Micrococcus sp. & $10^{5}$ \\
\hline & Firmicutes & Bacillaceae & Bacillus sp. & $10^{5}$ \\
\hline \multirow{4}{*}{ Well } & Firmicutes & Bacillaceae & Bacillus sp. & $9 \times 10^{6}$ \\
\hline & Actinobacteria & Streptomycetaceae & Streptomyces sp. & $3 \times 10^{6}$ \\
\hline & Firmicutes & Staphylococcaceae & Staphylococcus sp. & $2 \times 10^{6}$ \\
\hline & Firmicutes & Planococcaceae & Planococcus sp. & $2 \times 10^{5}$ \\
\hline \multirow{4}{*}{ Desert Steppe } & Firmicutes & Bacillaceae & Bacillus sp. & $7 \times 10^{6}$ \\
\hline & Firmicutes & Paenibacillaceae & Brevibacillus sp. & $3 \times 10^{5}$ \\
\hline & Firmicutes & Planococcaceae & Planococcus sp. & $8 \times 10^{4}$ \\
\hline & Actinobacteria & Brevibacteriaceae & Brevibacterium sp. & $5 \times 10^{4}$ \\
\hline
\end{tabular}

* CFU: colony forming unit.

\subsection{Characteristics of Detected Bacteria}

Seven bacterial species isolated from the soil of each collection site were identified (Table 2). Detailed information on the identification of the bacterial strains is given in Table S1. They were classified into two phyla, namely Firmicutes and Actinobacteria. Further classification placed four species in Firmicutes and three species in Actinobacteria. All bacteria classified as Firmicutes belonged to the order Bacillales of the class Bacilli. The class Actinobacteria is divided into two orders, namely Actinomycetales and Streptomycetales. Each family was classified into seven types: Bacillaceae, Micrococcaceae, Planococcaceae, Streptomycetaceae, Brevibacteriaceae, Staphylococcaceae, and Paenibacillaceae.

Firmicutes were the dominant bacteria in all collection sites in terms of phylum classification (Figure 2).

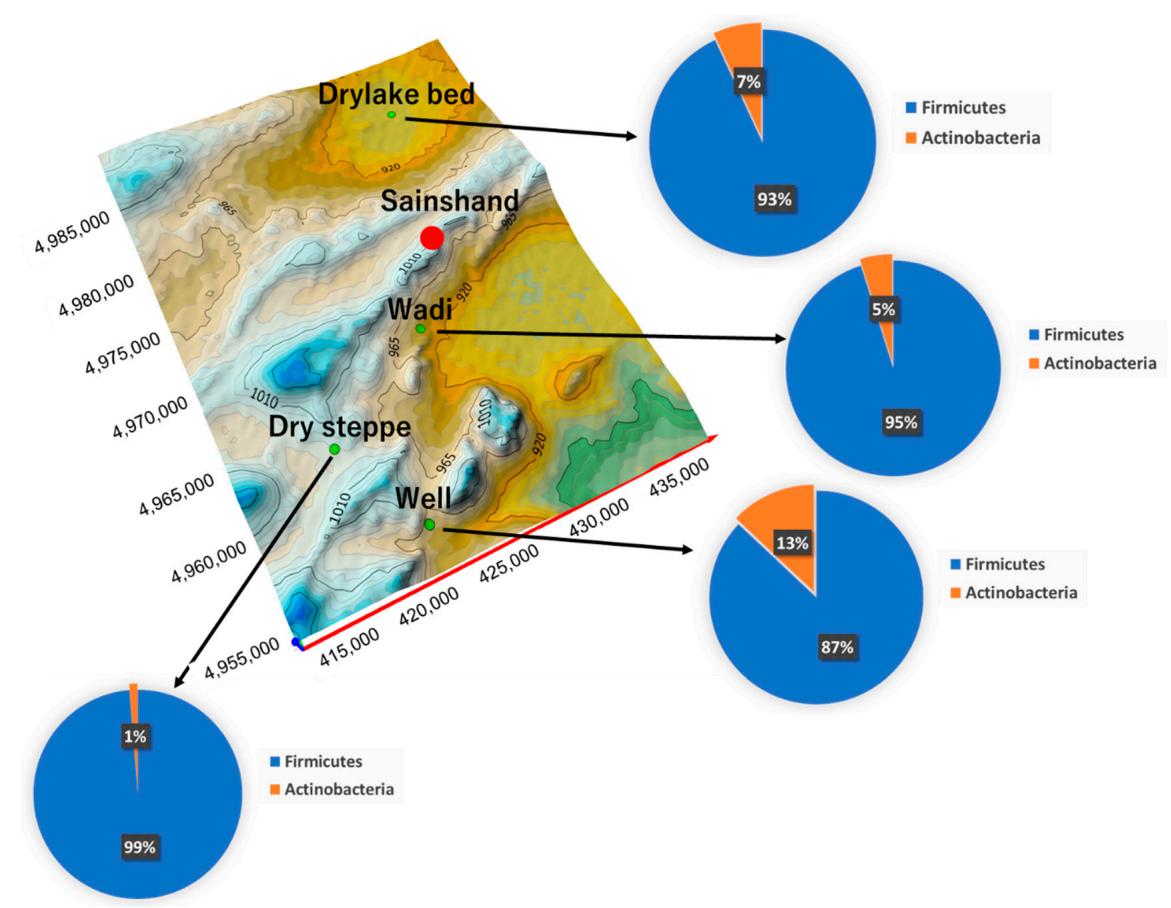

Figure 2. Geographical representation based on the phylum of bacteria isolated from the surface soil. The pie chart shows the ratio of identified bacteria classified into two phyla for each land type. The background image is 3D topographic contours using SRTM data (Where, values on the vertical and horizontal axes indicate distances (m) on UTM (Universal Transverse Mercator) North 48 zone and the World Geodetic System (WGS) 84 projection). 
Comparing strains isolated in each region at the family level resulted in several findings. Out of the three Bacillaceae, Micrococcaceae and Staphylococcaceae types, Bacillaceae was the most isolated bacterial type in DL. Three families were identified in WA, namely Planococcaceae, Micrococcaceae and Bacillaceae, with Planococcaceae being the most isolated in this area. Four families, namely Bacillaceae, Staphylococcaceae, Streptomycetaceae, and Planococcaceae, were identified in WE. In well, four strains were isolated, and three species were detected in almost the similar number and were more diverse than in other areas. Four families, namely Bacillaceae, Paenibacillaceae, Planococcaceae, and Brevibacteriaceae, were detected in DS, with Bacillaceae being diverse, as well as the most frequently detected.

Bacillaceae was ubiquitously detected in all sampling sites, and was a dominant bacterial species at $10^{5}-10^{6} \mathrm{CFU} \mathrm{g}{ }^{-1}$ in DL, WE and DS. In WA, Planococcaceae was the most frequently detected, but Bacillaceae abundance was low. Micrococcaceae was found in DL and WA. Staphylococcaceae was found in DL and WE. Streptomycetaceae was detected only in WE, while Planococcaceae and Brevibacteriaceae were detected only in DS (Figure 3).

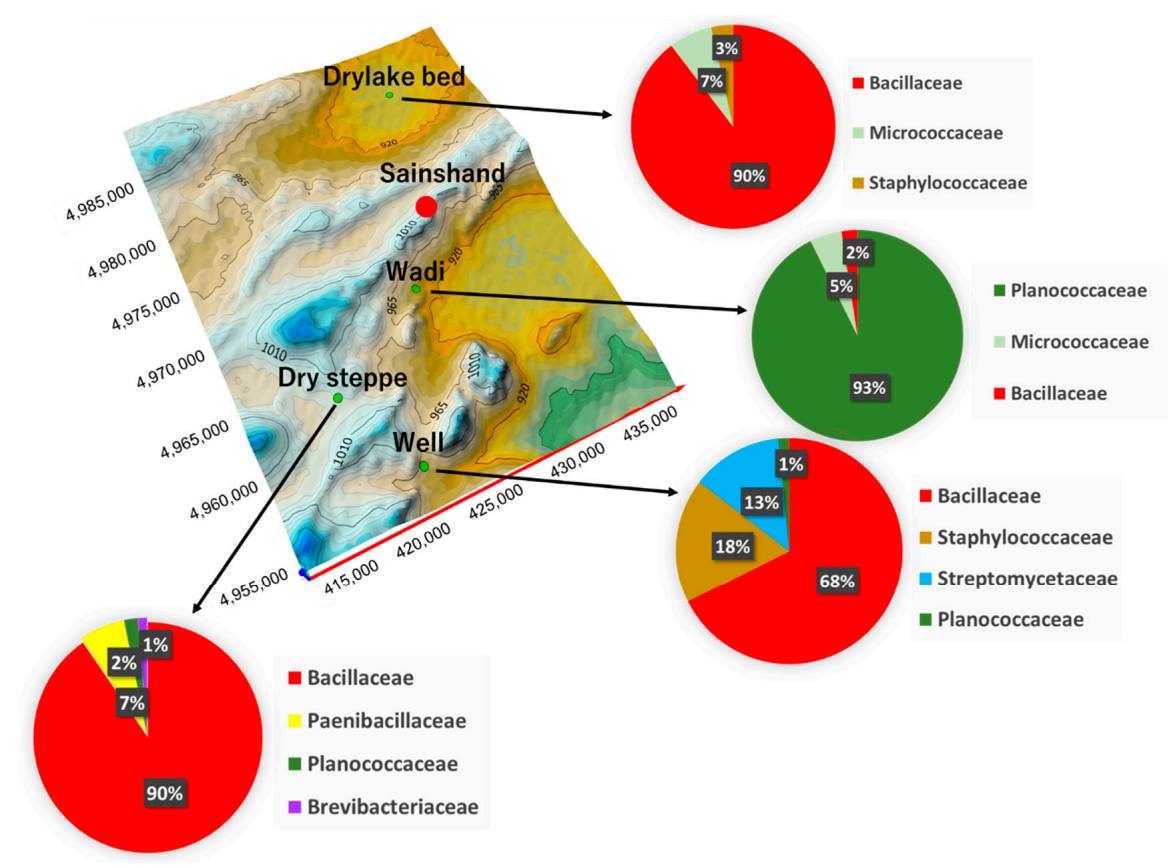

Figure 3. Geographical representation based on the family of bacteria isolated from surface soil. The pie chart shows the ratio of each land type for the identified family of bacteria. Similar distributions of bacteria have been confirmed in the dry lake bed and desert steppe, and various bacteria are distributed in the well. Wadi isolates are characterized by a different distribution of Planococcaceae than isolates from the other sample points. The background image is 3D topographic contours using SRTM data (Where, values on the vertical and horizontal axes indicate distances (m) on UTM (Universal Transverse Mercator) North 48 zone and the World Geodetic System (WGS) 84 projection).

\subsection{Bacterial Interrelationship by 16s rDNA Gene Phylogenetic Analysis}

The relationship among the bacteria detected based on the phylogenetic tree analysis of $16 \mathrm{~s}$ rDNA was examined for bacteria isolated from each sample site. Bacillaceae was roughly divided into four clusters and was a predominant bacterial species that survived diversely in all sites (Figure 4a). Planococcaceae was roughly divided into three clusters. These clusters were confirmed to spread to all clusters of WA and WE. The bacteria present in DL and DS were probably derived from the $3 \mathrm{WA}, 4 \mathrm{WA}$, and $8 \mathrm{WE}$ clusters. The $5 \mathrm{WE}$ and 10DS clusters originated differently from other regions, with WE exhibiting a high Planococcaceae diversity (Figure 4b). Similarly, Streptomycetaceae bacteria were distributed in WE; the presence of the bacteria was confirmed in DS and may have migrated from WE. Conversely, bacteria from the 2WA cluster were different from the others (Figure 4c). Micrococcaceae 
showed a distribution of diversity in WA, and were mainly distributed in WA and DL. Relatively closely related bacteria were distributed in DS and DL (Figure 4d). Staphylococcaceae were the predominant bacteria in DL. The bacteria were divided into two clusters, with one that was distributed from DL to the wells. The bacteria detected in DL were shown to be strains mainly isolated from animals by genetic analysis. As animal footprints and faces were identified in DL and WE, bacterial distribution may be dependent on animal movement rather than dust event migration (Figure 4e).

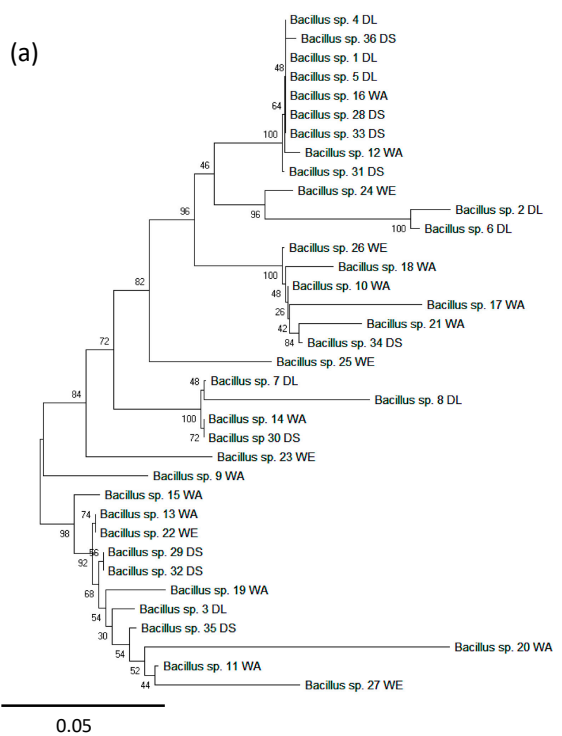

(b)
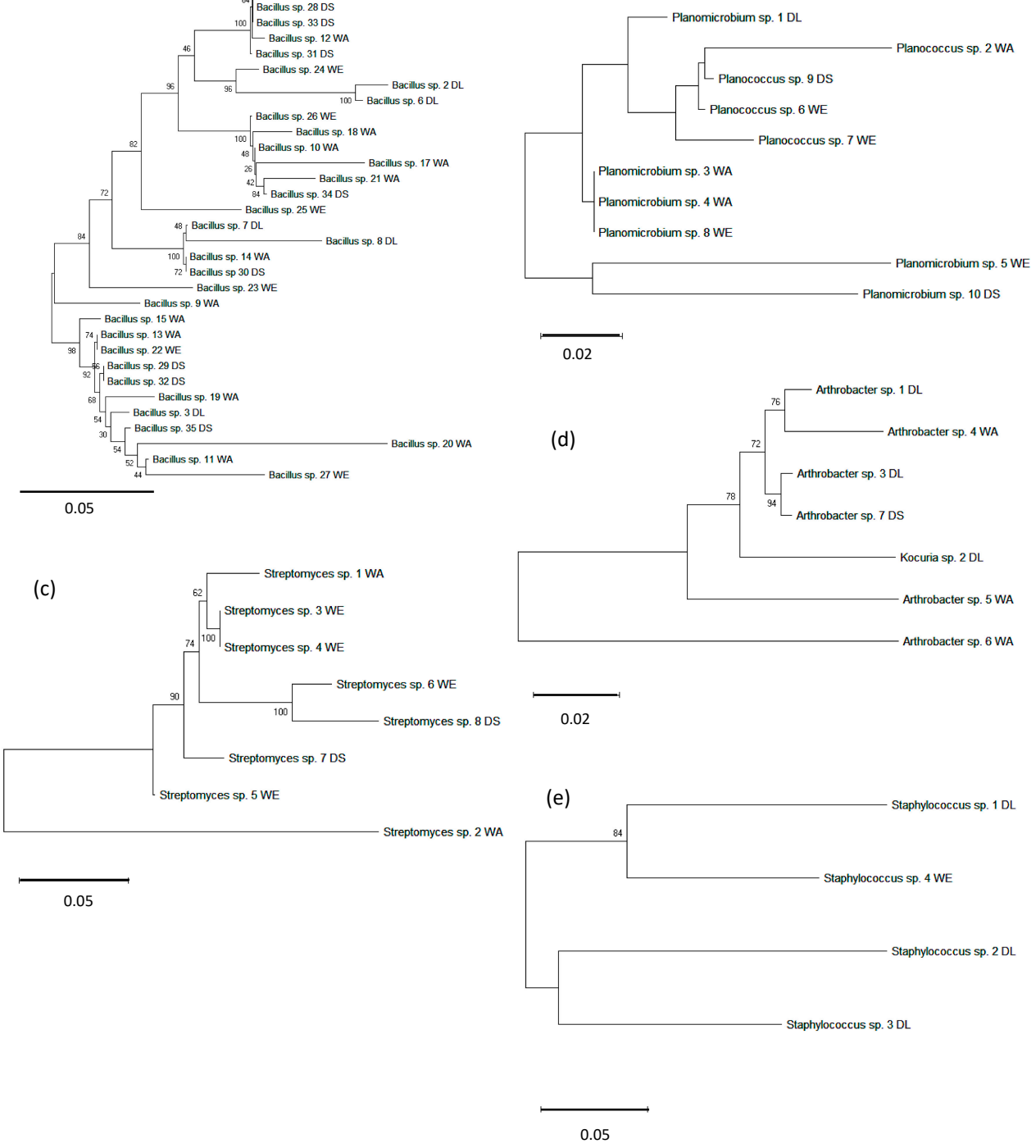

Figure 4. Phylogenetic tree analysis of $16 \mathrm{~s}$ rDNA of five dominant strains bacteria identified in the study site. The number and symbol on the display indicate the isolation number of each bacterium and the abbreviation of the isolation site (dry lake bed: DL, desert step: DS, wadi: WA, well: WE). (a) The phylogenetic tree analysis of $16 \mathrm{~s}$ rDNA at each isolation site is shown for Bacillaceae, which is the dominant strain in DS and DL among the surveyed sites. (b) A phylogenetic analysis of 16s rDNA is shown for Planococcaceae, which is the dominant strain in WA. (c) The phylogenetic tree analysis of $16 \mathrm{~s}$ rDNA is shown for Streptomycetaceae, which was relatively frequently identified in WE. (d) The phylogenetic tree analysis of 16s rDNA is shown for Micrococcaceae, mainly identified in DL and WA. (e) The phylogenetic analysis of 16s rDNA is shown for Staphylococcaceae, identified in WE and DL. The scale bar indicates the difference in the number of compared bases after multiple alignment (substitution per nucleotide position). 


\section{Discussion}

\subsection{Environment of Each Land Use and Detected Bacteria}

The present study confirmed regional differences in the water content of each sample site, specifically indicating that water content was significantly higher in DL than in other areas. DL was lower in altitude than the surrounding area, allowing various substances to accumulate, and possessed a higher water content than the other land types. On the other hand, DS exhibited a significantly lower temperature than the other land types at the same time of analysis. There was a significant relationship between the surface temperature of each land use and soil water content, but no correlation with the total number of bacteria in each land use. This finding suggested that the total number of bacteria in each land type was not affected by the soil water content and temperature within the measurement range. The confirmed diversity of bacterial species at each sample location was considered to be due to environmental conditions other than soil water content or to other characteristics of the land.

\subsection{Diversity of Detected Live Bacteria throughout Land Use}

The identified bacteria were derived from plants, the environment (e.g., soil), and animals. The two phyla of live bacteria were confirmed at the study site. Actinobacteria are generally soil-borne bacterial species. In addition, Firmicutes are bacterial species adapted to the dry and high temperature environment of the desert. Previous studies have shown that the Taklimakan Desert has a high proportion of Actinobacteria, Bacilli, Sphingobacteria, and Betaproteobacteria, similar to the Gobi Desert. A high proportion of Actinobacteria, Sphingobacteria, Betaproteobacteria, and Gammaproteobacteria, as well as bacterial species of human or animal origin have been confirmed in the Loess Plateau [38]. The Loess Plateau is a large agricultural area with several sources of humanand animal-derived material, including the input of compost [39]. The above results showed that bacterial species including Actinobacteria, Sphingobacteria, and Betaproteobacteria commonly existed in the tested sources of Asian dust. Additionally, Bacilli were also characteristically found in both the Taklimakan Desert and the Gobi Desert. Actinobacteria and Bacilli isolated in this study were suggested as bacteria commonly present in the Gobi Desert.

\subsection{Characteristics of Detected Bacteria on the Land Environment}

Bacillaceae are mostly found in the dry lake bed, which is a source of dust, and are reported to be soil-derived, livestock pathogens and symbiotic bacteria, and bacteria causing food poisoning. B. thuringiensis isolated from the surface soil of dry lakes exists in various natural environments including soil, plant foliage, fresh water, seabed sediments, and wastewater treatment facilities. It has attracted attention as an entomopathogenic bacterium that can replace chemical pesticides [40]. B. muralis has been reported to be separated from soil [41].

Research on the industrial microbial application of B. subtilis, which is ubiquitously present in soil and plants, and also exists in the gastrointestinal tract of ruminants and humans, is progressing [42]. $B$. cereus is an aerobic, spore-forming bacterium abundantly found in natural environments such as soil and sewage, which causes food poisoning [43].

Bacillus sp. are a stress-resistant bacterial group with a high potential for long-distance transport and vertical mixing along with dust (Kosa) [44]. Considering the characteristics of Bacillus sp., it is easily understood why they exist throughout the surface soil of the Gobi region. These species typically float up in the air during a dust event and are transported over long distances along with Asian dust $[45,46]$. It is speculated that this bacterium may spread widely among the regions and may be dispersed. The phylogenetic tree analysis suggested that Bacillaceae are distributed in the environment with the movement of the atmosphere (e.g., during dust events).

Arthrobacter sp., from the Micrococcaceae family, are a major group of soil bacteria; various Actinomycetes have been isolated from the desert environment, and the bacteria exhibits a high growth temperature range $\left(15-50^{\circ} \mathrm{C}\right)$ [47]. Planococcaceae was found most frequently in the WA surface soil; 
similar results were obtained in WE and DS. Bacterial species such as Micrococcaceae and Bacillaceae were also found in DL. The presence of multiple common bacterial species in WA may be related to topographical features, with factors such as precipitation believed to affect the environment in surrounding areas. It is speculated that bacterial migration may originate from WA.

The highest total number of bacteria among the four land uses was detected in WE, and included Staphylococcaceae Staphylococcus sp. These animal-derived bacterial species have been identified in wells, which provide drinking water, essential for life, to livestock and wild animals. This finding is very distinctive and may be related to environmental factors. The distribution of Streptomycetaceae Streptomyces sp. occurs in soils of India, Russia, Morocco, and Japan. The present study revealed that these bacteria also exist in the Gobi Desert. Many of the Actinomycetes belong to this group of bacterial species, and are naturally derived from soil and plants [48,49]. In addition, these bacteria are halophilic, resistant to environmental stress, and known to survive air movement [44].

The bacteria detected in DS were all environmentally derived. The most frequently detected Bacillaceae and Paenibacillaceae are present in various environments, including soil, water, rhizosphere, indoor plants, and insect larva. Brevibacteriaceae, detected only in this land type, are soil-derived bacteria. This area is characterized by the growth of plants, highlighting the need for the different bacteria to be isolated. The symbiotic environment of plants may be a factor in the difficult distribution of bacteria by dust events. Interestingly, bacteria detected in the surface soil of the Gobi study site were also found in Japanese dust. Considering that surface soil in the Gobi region is transported overseas every year as yellow sand, this phenomenon suggests that it may move together with the dust. It is therefore speculated that bacteria distributed in both areas are transferred via atmospheric circulation. Future research should include a focus on transboundary microbial migration.

\section{Conclusions}

In conclusion, the present study confirmed the presence of live bacteria in the Gobi Desert via the culture method. Detected bacteria displayed land-use-dependent diversity, indicating the possibility of migration due to dust events, and that environmental bacteria may affect animals and humans. When environmental bacteria have zoonotic properties, they directly infect livestock or humans, or indirectly infect humans via animals. Although it exists in the environment, it has the potential to be versatile due to its sensitivity. In this study, seven dominant bacterial strains survived under environmental stress in the dust-producing area of the Gobi region. Their distribution was characterized by the environmental factors of the land, and they may be transported over long distances along with dust particles. Bacteria of animal origin were detected in the study areas which indicated the presence of animals. This suggested that a variety of bacterial species may be transported along with the generation of Asian dust, and scattered. From a global perspective, there is a possibility that malignant infectious disease pathogens will be scattered to other regions together with dust, and affect animals in these areas [6,7]. It has been confirmed at the DNA level that Bacillus anthracis can disperse via aerosols [50]. As a One Health concept, it will be possible to assess the risk of bacteria in the environment by comparing drug resistance gene markers in common bacteria present in the environment, animals and humans. Based on these reports, it is important to further the investigation of dust events under the One Health concept in order to balance the ecosystem as well as ensure the safety of human and animal health.

Supplementary Materials: The following are available online at http://www.mdpi.com/2073-4433/11/9/893/s1, Table S1: Identification of bacterial strains detected from the land surface.

Author Contributions: Conceptualization, K.H. and B.H.; methodology, K.H. and B.H.; software, T.M., B.H. and P.T.; validation, B.H., T.M. and K.H.; formal analysis, T.M., K.B. and P.T.; investigation, T.M., P.T., K.B., K.H. and B.H.; resources, B.H., K.B. and K.H.; data curation, T.M., B.H. and K.H.; writing-original draft preparation, K.H., and T.M.; writing-review and editing, K.H. and B.H.; visualization, B.H.; supervision, K.H. and B.H.; project administration, K.H. and B.H.; funding acquisition, K.H., K.B. and B.H. All authors contributed equally. All authors have read and agreed to the published version of the manuscript. 
Funding: This work was funded by JSPS KAKENHI Grant Numbers: 25550079, JP16H02703, JP18H03608 and JP19H04362; this research also received research support from the joint research program of the Institute for Space-Earth Environmental Research, Nagoya University as an external fund.

Acknowledgments: We would like to thank Kenji Kai (Ibaraki University) for providing valuable information and comments regarding the research, and Morine Kuribayashi (Rakuno Gakuen University) for her research assistance to the study. We would like to thanks the Information and Research Institute of Meteorology, Hydrology and Environment, National Agency for Meteorology and Environmental Monitoring, Mongolia for kindly cooperating. This work was supported by JSPS KAKENHI (Grant Numbers JP16H02703, JP18H03608 and JP19H04362), with part of the work carried out by the joint research program of the Institute for Space-Earth Environmental Research, Nagoya University.

Conflicts of Interest: The authors declare no conflict of interest.

\section{References}

1. Miller, R.S.; Pepin, K.M. Board Invited Review: Prospects for improving management of animal disease introductions using disease-dynamic models. J. Anim. Sci. 2019, 97, 2291-2307. [CrossRef] [PubMed]

2. Yadav, M.P.; Singh, R.K.; Malik, Y.S. Emerging and transboundary animal viral diseases: Perspectives and preparedness. Emerg. Transbound. Anim. Viruses 2020, 1-25. [CrossRef]

3. Torres-Velez, F.; Havas, K.A.; Spiegel, K.; Brown, C. Transboundary animal diseases as re-emerging threats -Impact on One Health. Semin. Diagn. Pathol. 2019, 36, 193-196. [CrossRef] [PubMed]

4. Lelieveld, J.; Pöschl, U. Chemists can help to solve the air-pollution health crisis. Nature 2017, 551, $291-293$. [CrossRef] [PubMed]

5. Akhtar, R.; Palagiano, C. Climate Change and Air Pollution: The Impact on Human Health in Developed and Developing Countries; Springer International Publishing: Cham, Switzerland, 2018.

6. Nakao, M.; Ishihara, Y.; Kim, C.-H.; Hyun, I.-G. The impact of air pollution, including Asian sand dust, on respiratory symptoms and health-related quality of life in outpatients with chronic respiratory disease in Korea: A panel study. J. Prev. Med. Public Health 2018, 51, 130-139. [CrossRef] [PubMed]

7. Polymenakou, P.N.; Mandalakis, M.; Stephanou, E.G.; Tselepides, A. Particle size distribution of airborne microorganisms and pathogens during an intense African dust event in the Eastern Mediterranean. Environ. Health Perspect. 2008, 116, 292-296. [CrossRef]

8. Shimizu, A.; Sugimoto, N.; Matsui, I.; Arao, K.; Uno, I.; Murayama, T.; Kagawa, N.; Aoki, K.; Uchiyama, A.; Yamazaki, A. Continuous observations of Asian dust and other aerosols by polarization lidars in China and Japan during ACE-Asia. J. Geophys. Res. Atmos. 2004, 109, 1-14. [CrossRef]

9. Jugder, D.; Shinoda, M.; Kimura, R.; Batbold, A.; Amarjargal, D. Quantitative analysis on windblown dust concentrations of $\mathrm{PM}_{10}\left(\mathrm{PM}_{2.5}\right)$ during dust events in Mongolia. Aeolian Res. 2014, 14, 3-13. [CrossRef]

10. Shao, Y. Physics and Modelling of Wind Erosion; Springer Science \& Business Media: New York, NY, USA, 2008.

11. Hoshino, B.S.R.; Sofue, Y.; Demura, Y.; Purevsuren, T.; Hai, Y. Social transition from nomad to settlement in the Mongolian Steppe and its impact on Japan. Assoc. Kyosei Stud. 2015, 9, 1-27.

12. Demura, Y.; Hoshino, B.; Baba, K.; McCarthy, C.; Sofue, Y.; Kai, K.; Purevsuren, T.; Hagiwara, K.; Noda, J. Determining the frequency of dry lake bed formation in semi-arid Mongolia from satellite data. Land 2017, 6, 88. [CrossRef]

13. Sofue, Y.; Hoshino, B.; Demura, Y.; Kai, K.; Baba, K.; Nduati, E.; Kondoh, A.; Sternberg, T. Satellite monitoring of vegetation response to precipitation and dust storm outbreaks in Gobi Desert regions. Land 2018, 7, 19. [CrossRef]

14. Kim, H.-S.; Kim, D.-S.; Kim, H.; Yi, S.-M. Relationship between mortality and fine particles during Asian dust, smog-Asian dust, and smog days in Korea. Int. J. Environ. Health Res. 2012, 22, 518-530. [CrossRef] [PubMed]

15. Maki, T.; Lee, K.C.; Kawai, K.; Onishi, K.; Hong, C.S.; Kurosaki, Y.; Shinoda, M.; Kai, K.; Iwasaka, Y.; Archer, S.D.J.; et al. Aeolian dispersal of bacteria associated with desert dust and anthropogenic particles over continental and oceanic surfaces. J. Geophys. Res. Atmos. 2019, 124, 5579-5588. [CrossRef]

16. Sugimoto, N.; Uno, I.; Nishikawa, M.; Shimizu, A.; Matsui, I.; Dong, X.; Chen, Y.; Quan, H. Record heavy Asian dust in Beijing in 2002: Observations and model analysis of recent events. Geophys. Res. Lett. 2003, 30, 1640. [CrossRef] 
17. Jugder, D.; Shinoda, M.; Sugimoto, N.; Matsui, I.; Nishikawa, M.; Park, S.-U.; Chun, Y.-S.; Park, M.-S. Spatial and temporal variations of dust concentrations in the Gobi Desert of Mongolia. Glob. Planet. Chang. 2011, 78, 14-22. [CrossRef]

18. Hoshino, B.; Sofue, Y.; Demura, Y.; Purevsuren, T.; Kuribayashi, M.; Baba, K.; Zoljargal, E.; Hagiwara, K.; Noda, J.; Kawano, K.; et al. Detection of dry lake beds formation and estimate of environmental regime shift in semi-arid region. J. Arid Land Stud. 2018, 28, 109-113.

19. Okada, K.; Naruse, H.; Tanaka, T.; Nemoto, O.; Iwasaka, Y.; Wu, P.-M.; Ono, A.; Duce, R.A.; Uematsu, M.; Merrill, J.T.; et al. X-ray spectrometry of individual Asian dust-storm particles over the Japanese islands and the North Pacific Ocean. Atmos. Environ. Part A Gen. Top. 1990, 24, 1369-1378. [CrossRef]

20. Park, S.H.; Song, C.B.; Kim, M.C.; Kwon, S.B.; Lee, K.W. Study on size distribution of total aerosol and water-soluble ions during an Asian dust storm event at Jeju Island, Korea. Environ. Monit. Assess. 2004, 93, 157-183. [CrossRef]

21. Ichinose, T.; Nishikawa, M.; Takano, H.; Sera, N.; Sadakane, K.; Mori, I.; Yanagisawa, R.; Oda, T.; Tamura, H.; Hiyoshi, K.; et al. Pulmonary toxicity induced by intratracheal instillation of Asian yellow dust (Kosa) in mice. Environ. Toxicol. Pharmacol. 2005, 20, 48-56. [CrossRef]

22. Yamaguchi, N.; Baba, T.; Ichijo, T.; Himezawa, Y.; Enoki, K.; Saraya, M.; Li, P.-F.; Nasu, M. Abundance and community structure of bacteria on Asian dust particles collected in Beijing, China, during the Asian dust season. Biol. Pharm. Bull. 2016, 39, 68-77. [CrossRef]

23. Takeuchi, S.; Kojima, H.; Saito, I.; Jin, K.; Kobayashi, S.; Tanaka-Kagawa, T.; Jinno, H. Detection of 34 plasticizers and 25 flame retardants in indoor air from houses in Sapporo, Japan. Sci. Total Environ. 2014, 491-492, 28-33. [CrossRef] [PubMed]

24. Tang, K.; Huang, Z.; Huang, J.; Maki, T.; Zhang, S.; Shimizu, A.; Ma, X.; Shi, J.; Bi, J.; Zhou, T.; et al. Characterization of atmospheric bioaerosols along the transport pathway of Asian dust during the Dust-Bioaerosol 2016 Campaign. Atmos. Chem. Phys. 2018, 18, 7131-7148. [CrossRef]

25. Fröhlich-Nowoisky, J.; Kampf, C.J.; Weber, B.; Huffman, J.A.; Pöhlker, C.; Andreae, M.O.; Lang-Yona, N.; Burrows, S.M.; Gunthe, S.S.; Elbert, W.; et al. Bioaerosols in the Earth system: Climate, health, and ecosystem interactions. Atmos. Res. 2016, 182, 346-376. [CrossRef]

26. Maki, T.; Kakikawa, M.; Kobayashi, F.; Yamada, M.; Matsuki, A.; Hasegawa, H.; Iwasaka, Y. Assessment of composition and origin of airborne bacteria in the free troposphere over Japan. Atmos. Environ. 2013, 74, 73-82. [CrossRef]

27. Delfino, R.J.; Sioutas, C.; Malik, S. Potential role of ultrafine particles in associations between airborne particle mass and cardiovascular health. Environ. Health Perspect. 2005, 113, 934-946. [CrossRef]

28. Martiny, J.B.; Bohannon, B.J.; Brown, J.H.; Colwell, R.K.; Fuhrman, J.A.; Green, J.L.; Horner-Devine, M.C.; Kane, M.; Krumins, J.A.; Kuske, C.R.; et al. Microbial biogeography: Putting microorganisms on the map. Nat. Rev. Microbiol. 2006, 4, 102-112. [CrossRef]

29. Griffin, D.W. Atmospheric movement of microorganisms in clouds of desert dust and implications for human health. Clin. Microbiol. Rev. 2007, 20, 459-477. [CrossRef]

30. Natsagdorj, L.; Jugder, D.; Chung, Y.S. Analysis of dust storms observed in Mongolia during 1937-1999. Atmos. Environ. 2003, 37, 1401-1411. [CrossRef]

31. Digital Elevation-SRTM (The Shuttle Radar Topography Mission). Available online: https: //www.usgs.gov/centers/eros/science/usgs-eros-archive-digital-elevation-shuttle-radar-topographymission-srtm-1-arc?qt-science_center_objects=0\#qt-science_center_objects (accessed on 20 August 2020).

32. ESA Sentinel 2 Data. Available online: https://scihub.copernicus.eu/ (accessed on 20 August 2020).

33. Golden Software Surfer. Available online: https://www.goldensoftware.com/products/surfer (accessed on 20 August 2020).

34. Rashki, A.; Kaskaoutis, D.G.; Goudie, A.S.; Kahn, R.A. Dryness of ephemeral lakes and consequences for dust activity: The case of the Hamoun drainage basin, southeastern Iran. Sci. Total Environ. 2013, 463-464, 552-564. [CrossRef]

35. Garrity, G.M.; Bell, J.A.; Lilburn, T.G. Taxonomic outline of the prokaryotes. In Bergey's Manual of Systematic Bacteriology; Springer: New York, NY, USA; Berlin/Heidelberg, Germany, 2004.

36. Bio Edit (a Biological Sequence Alignment Editor, Version 7.0.9). Available online: https://bioedit.software. informer.com/7.0/ (accessed on 20 August 2020). 
37. MEGA-X (Molecular Evolutionary Genetics Analysis across Computing Platforms, Verson 10). Available online: https://www.megasoftware.net (accessed on 20 August 2020).

38. Yang, Y.; Dou, Y.; An, S. Testing association between soil bacterial diversity and soil carbon storage on the Loess Plateau. Sci. Total Environ. 2018, 626, 48-58. [CrossRef]

39. Kenzaka, T.; Sueyoshi, A.; Baba, T.; Li, P.; Tani, K.; Yamaguchi, N.; Nasu, M. Soil microbial community structure in an Asian dust source region (Loess plateau). Microbes Environ. 2010, 25, 53-57. [CrossRef] [PubMed]

40. Griffiths, B.S.; Caul, S.; Thompson, J.; Birch, A.N.E.; Scrimgeour, C.; Andersen, M.N.; Cortet, J.; Messéan, A.; Sausse, C.; Lacroix, B.; et al. A comparison of soil microbial community structure, protozoa and nematodes in field plots of conventional and genetically modified maize expressing the Bacillus thuringiensis CryIAb toxin. Plant Soil 2005, 275, 135-146. [CrossRef]

41. Yadav, A.N.; Sachan, S.G.; Verma, P.; Saxena, A.K. Bioprospecting of plant growth promoting psychrotrophic Bacilli from the cold desert of north western Indian Himalayas, Indian. J. Exp. Biol. 2016, 54, 142-150.

42. van Dijl, J.M.; Hecker, M. Bacillus subtilis: From soil bacterium to super-secreting cell factory. Microb. Cell Fact. 2013, 12, 3. [CrossRef] [PubMed]

43. Dierick, K.; Van Coillie, E.; Swiecicka, I.; Meyfroidt, G.; Devlieger, H.; Meulemans, A.; Hoedemaekers, G.; Fourie, L.; Heyndrickx, M.; Mahillon, J. Fatal family outbreak of Bacillus cereus-associated food poisoning. J. Clin. Microbiol. 2005, 43, 4277-4279. [CrossRef] [PubMed]

44. Maki, T.; Suzuki, S.; Kobayashi, F.; Kakikawa, M.; Tobo, Y.; Yamada, M.; Higashi, T.; Matsuki, A.; Hong, C.; Hasegawa, H.; et al. Phylogenetic analysis of atmospheric halotolerant bacterial communities at high altitude in an Asian dust (KOSA) arrival region, Suzu City. Sci. Total Environ. 2010, 408, 4556-4562. [CrossRef]

45. Maki, T.; Hara, K.; Iwata, A.; Lee, K.C.; Kawai, K.; Kai, K.; Kobayashi, F.; Pointing, S.B.; Archer, S.; Hiroshi Hasegawa, H.; et al. Variations in airborne bacterial communities at high altitudes over the Noto Peninsula (Japan) in response to Asian dust events. Atmos. Chem. Phys. 2017, 17, 19. [CrossRef]

46. Zhou, H.; Wang, X.; Li, Z.; Kuang, Y.; Mao, D.; Luo, Y. Occurrence and distribution of urban dust-associated bacterial antibiotic resistance in Northern China. Environ. Sci. Technol. Lett. 2018, 5, 50-55. [CrossRef]

47. Takahashi, Y. Exploitation of new microbial resources for bioactive compounds and discovery of new Actinomycetes. Actinomycetologica 2004, 18, 54-61. [CrossRef]

48. Songara, D.; Kaur, S.; House, K. DNA based identification and characterization of thermophilic Streptomyces sp. from desert soil of Rajasthan. Int. J. Curr. Microbiol. Appl. Sci. 2013, 2, 418-427.

49. Idris, H.; Labeda, D.P.; Nouioui, I.; Castro, J.F.; del Carmen Montero-Calasanz, M.; Bull, A.T.; Asenjo, J.A.; Goodfellow, M. Streptomyces aridus sp. Nov.; isolated from a high altitude Atacama Desert soil and emended description of Streptomyces noboritoensis Isono et al. 1957. Antonie Leeuwenhoek 2017, 110, 705-717. [CrossRef] [PubMed]

50. Nicholas, A.B.; Thissen, J.B.; Gardner, S.N.; McLoughlin, K.S.; Fofanov, V.Y.; Koshinsky, H.; Ellingson, S.R.; Brettin, T.S.; Jackson, P.J.; Jaing, C.J. Detection of Bacillus anthracis DNA in complex soil and air samples using next-generation sequencing. PLoS ONE 2013, 8, e73455.

(C) 2020 by the authors. Licensee MDPI, Basel, Switzerland. This article is an open access article distributed under the terms and conditions of the Creative Commons Attribution (CC BY) license (http://creativecommons.org/licenses/by/4.0/). 